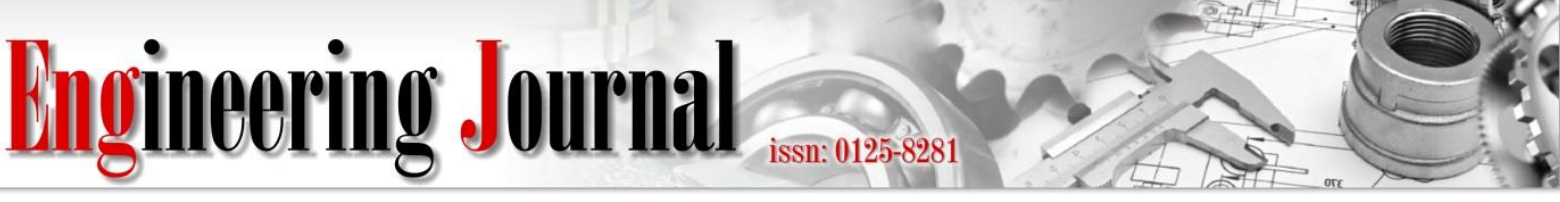

Article

\section{Perception of Lecturers and Students Regarding the Illuminance in the Lecture Theatres and Tutorial Rooms: Case Study in Universiti Tunku Abdul Rahman (UTAR)}

\author{
Shalini Sanmargaraja ${ }^{a,}{ }^{*}$, Tew Li Wei ${ }^{b}$, Vignes Ponniah ${ }^{c}$, Abdul Lateef A. Olanrewaju ${ }^{\mathrm{d}}$, \\ and Khor Soo Cheen ${ }^{\mathrm{e}}$ \\ Department of Construction Management, Faculty of Engineering and Green Technology, Universiti \\ Tunku Abdul Rahman (UTAR), Jalan Universiti, Bandar Barat, 31900 Kampar, Perak, Malaysia \\ E-mail: a,*shalinis@utar.edu.my (Corresponding author), bliwei.1536@1utar.my, cvignes@utar.edu.my, \\ dolanrewaju@utar.edu.my, ekhorsc@utar.edu.my
}

\begin{abstract}
Even though artificial lighting is widely used nowadays, it has several negative impacts on human health. Therefore, this paper reported research that comparing the illuminance level in the learning environment in UTAR and recognizing the users' insights on the illuminance level. Lux meter and questionnaires were used for data collection. Questionnaires were administered to 312 respondents. The results show that the illuminance level in some of the tutorial rooms is too bright and left on even when the rooms are empty. From the descriptive analysis, it is found that almost all the respondents are satisfied with the illuminance level in both research venues. Based on the t-test, it is found the significance for pair 1 and pair 2 is greater than 0.05 . Hence, there is no similarity between both research venues. Pair 1 is about the lighting condition preferred by the respondents, while pair 2 is about the condition in both research venues which includes the existence of glaring vision, headache, eye tiredness, and conditions that affect student performance. This paper concludes by suggesting that individual switches be provided for each of the bulbs.
\end{abstract}

Keywords: Energy saving, illuminance, learning environment, perception, university.

ENGINEERING JOURNAL Volume 25 Issue 7

Received 10 June 2021

Accepted 8 July 2021

Published 31 July 2021

Online at https:// engj.org/

DOI:10.4186/ej.2021.25.7.83 


\section{Introduction}

Previously, natural lighting was the major light source in buildings before the creation of artificial lighting in the year 1879 [1]. Previously, artificial lighting was mostly utilized to compensate for natural lighting where it is difficult to obtain natural lighting, especially during the winter seasons. In recent days, artificial lighting has become the primary resource to brighten working spaces and homes. Though artificial lighting is considered the greatest invention of humankind, there is a growing concern about the side effects of artificial lighting systems $[1]$.

Indoor illumination is one of the vital elements in the Indoor Environment Quality (IEQ) assessment. Indoor Environment Quality was established to create an appropriate indoor environment that strengthens the occupant's health, well-being, and comfort. IEQ prioritizes the user's health by assessing the environmental aspects including illumination quality, acoustical quality and visual, thermal comfort, and air quality. The illumination quality is one of the key considerations in IEQ measurement that should not be forgotten [2].

Adding to this, $21 \%$ of green building evaluation criteria for non-residential buildings, namely academic institutions are based on IEQ elements. However, IEQ is least considered as the main priority in most management and development planning. Nowadays, the majority of the people spend most of their time indoors, whether it can be in the school, office or homes. Therefore, the indoor environment surely affects their health and well-being. A decent illumination performance contributes to emotional and physical benefits by reducing overall energy utilization. Hence, the indoor illumination should be kept at the optimal level [3].

By enhancing natural lighting, students' attention, intellectual presentation, alertness span, and attitudes in the learning venues can be improved [4]. Daylight distributions are influenced by the depth of the learning venues. For example, if the Window-to-Floor Ratio (WFR) is greater than $20 \%$, the sunlight supply is unacceptable because of its larger depth of the classroom's layout design. Arabi, et al. [5] stated that there are no specific guidelines on the preferred illuminance levels and discomfort level for students. Table 1 contains the guidelines for the ranges of office illuminance levels that are refereed for schools and colleges.

Many reasons explain pondering daylight as a valuable light source in almost every type of buildings, especially in learning institutions. The solid reason for selecting natural light is because the quality of natural light is better than any artificial lighting for reading and writing purposes [5]. The luminous efficiency of daylight in Malaysia is outstanding and could serve most of the required luminosity during the day [5]. If the students have excellent daylighting in their learning institution's interior environment, they will excel in their academics. Insufficient learning environment brightness, especially on the working desk level where most of the reading and writing activities will take place leads to weak attention and poor performance. Previous research revealed that a poorly designed classroom affects the student's grades. In learning institution-building daylight is a vital design criterion rising from human requirements and environmental sustainability [6].

Table 1. Illuminance level based on jobs [5].

\begin{tabular}{ccc}
\hline Job & $\begin{array}{c}\text { Illuminance Level } \\
\text { (foot candles) }\end{array}$ & $\begin{array}{c}\text { Illuminance } \\
\text { level (lux) }\end{array}$ \\
\hline $\begin{array}{c}\text { Reading } \\
\text { printed } \\
\text { material }\end{array}$ & 30 & 323 \\
$\begin{array}{c}\text { Reading pencil } \\
\text { writing }\end{array}$ & 70 & 753 \\
$\begin{array}{c}\text { Reading good } \\
\text { duplicated } \\
\text { materials }\end{array}$ & 30 & 323 \\
\hline
\end{tabular}

\subsection{Standards and Guidelines}

Based on several guidelines and standards, the minimum glazing factor of $2 \%$ should only be highlighted when $75 \%$ of occupied areas in a building space are occupied to carry out activities such as reading and writing [7]. Generally, intensity and illuminance are spotted by the accessibility of the daylight through the reflection of the size of a window opening, furniture, office material, and layout settings [7].

Many daylight studies were carried out in a nonreligious school used table with $800 \mathrm{~mm}$ to $900 \mathrm{~mm}$ working plane height [8]. Different standards and guidelines suggested that the appropriate illuminance level for any learning spaces should be between 300 lux to 500 lux. Almost all the public schools in Malaysia had insufficient illuminance levels in the classrooms, whereby only 25 percent of the selected public schools managed to achieve the recommended standards and guidelines. Other than that, due to the insufficient architectural standards and improper designs, it is not difficult to find a school building that has poor performance and energy efficiency in Malaysia. Based on daily activity, all the lights will usually be switched on throughout the day even during recess time. By doing this, the heat in the building will be increased and there will be a need to use an air conditioning system to lower the temperature to provide a comfortable environment. Other than health, there are other benefits provided by suitable daylight such as lowering the cooling and lighting energy expenses. Cooling cost can be lowered with a suitable daylight design for a building which will lessen the overall heat inside the building [6].

Each country has recognized a customize illuminance standard based on its unique climate and geographic conditions. For example, in Singapore, SS531:2006 was formed by the Technical Committee on Lamps and Related Equipment, under the horizon of the Electrical and Electronic Standards Committee, the suggested range 
of illuminance in the classroom is ranged between $300-500$ lux where else in the United Kingdom and the United States, the suggested design illuminance for different types of the classroom as in the Code for Interior Lighting ranges from 300 lux to 500 lux. Illuminance level recommended in GB50034-2204 Standard for lighting design of buildings in China is 300 lux where else in Japan, the recommended illuminance level for classrooms is 200 lux to 750 lux. In Indonesia, the recommended illumination level for the classroom is within 250 lux to 300 lux under the Indonesian National Standard SNI 036197-2000. In Malaysia, the recommended illuminance level is 300 lux to 500 lux under Malaysia Standard
MS1525:2007 Code of Practice on Energy Efficiency and Use of Renewable Energy for Non-Residential Buildings [2].

The recommended illuminance level for the learning environment by various standards and guidelines is shown in Table 2. Malaysian standards, IESNA and Zumtobel recommend illuminance level in the range between 300 lux to 500 lux where else Philippines' Education Facilities Manual (EFM) recommended a lower range between 215 lux to 430 lux [8]. Illuminance level recommended by Malaysian standards and guidelines was used as the benchmark for this study.

Table 2. Standards and guidelines on illuminance level [8].

\begin{tabular}{ccccccc}
\hline $\begin{array}{c}\text { Standards } \\
\text { and } \\
\text { Guidelines }\end{array}$ & OSHA & $\begin{array}{c}\text { Malaysia } \\
\text { MS1525 }\end{array}$ & JKR & Zumtobel & $\begin{array}{c}\text { Others } \\
\text { EFM }\end{array}$ & IESNA \\
\hline $\begin{array}{c}\text { General } \\
\begin{array}{c}\text { Teaching Area } \\
\text { Library }\end{array}\end{array}$ & 300 & $300-500$ & $300-500$ & 300 & $215-430$ & $300-500$ \\
\hline
\end{tabular}

\subsection{Effects of Poor Illuminance}

Inadequate natural lighting often causes visual exhaustion or eye strain because the normal fit eyes cannot be overstrained. Lack of lighting can damage the eye tissues. Poor lighting effect indirectly to the natural reaction such as inadequate luminance or concealing reflections like getting closer to the specific job or changing the different direction by implementing uncommon positions that lead to other types of stress, such as back pain. In the learning institutions like schools and colleges, poor lighting causes visual discomfort [3].

According to Energy Efficiency and Use of Renewable Energy for Non-Residential Buildings-Code of Practice (MS1525:2014), lighting should provide an appropriate visual environment in a specific space for example adequate and appropriate lighting for performing wide of a range of regular jobs and for the creation of wanted looks. The designated color rendering index (CRI) for a specific job should also be prudently decided concurrently with the lighting intensity [9]. Indoor spaces will be frequently complained by the users, especially on their lighting distraction and high brightness which can cause visual discomfort and reduce their performance [10].

The two factors which have more effects on humans' moods are the bright illuminance together with the low color temperature turns people to feel warmer and uneasy, while dim illuminance together with high color temperature may turn someone to feel unhappy and uneasy $[11,12]$. Indirect lighting or ambient lighting turns someone to feel nervous, tense, and exhausted where else people can perform better indirect lighting. Hence, it can be concluded that direct lighting creates positive moods and indirect lighting creates negative moods [13, 14]. [15,
16] stated that students become calm and attentive in the classroom activities in the dim classroom compared to a bright classroom. Many prefer to work in daylight compared to artificial lighting because it is more pleasant, this is the main reason why people like to sit at the table next to the windows which have direct sunlight access [17].

Previous research shows that many suffered from eyes strain due to lack of illuminance level and lack of interest if working in a windowless room, natural lighting is always has been considered as the best source of lighting because it promotes the users' performance, can stay at work longer without getting exhausted and lesser absenteeism [18, 19, 20, 21, 22].

There is similar research that was conducted in public universities in Malaysia to determine the lighting performance in the classrooms. The research found that not all the lux levels in the classrooms were within the standards and guidelines recommended in Malaysia. A long working hour requires better illuminance to avoid fatigue and learning inefficiency [8]. Therefore, this research aims to contrast the illuminance level in lecture theaters and tutorial rooms in UTAR and to determine the users' insights on the illuminance level in both of the research venues in UTAR. The goal of this research is to survey from two (2) dimensions which are measuring the illuminance level in the tutorial rooms and lecture theatre and to determine the perceptions of the direct users of those spaces namely lecturers and students.

\section{Methodology}

Primary data were collected using two methods (2) namely illuminance reading using Lux Meter and perceptions of the direct users are measured using questionnaires. This research was conducted in lecture 
theatres and tutorial rooms in UTAR Kampar Campus. Twenty-two (22) lecture theatres in four (4) different blocks and eighty (80) tutorial rooms in four (4) different blocks were selected for this research. These venues are chosen due to it is frequently used by the staff and students compared to other blocks. The readings from the Lux Meter are taken inside the venues, were taken during a gloomy sky and partially cloudy condition at 12 noon. Four (4) points were selected in lecture theatres and four (4) points were selected in tutorial rooms so that experiments using Lux Meter can be performed. Initially, the research venues were divided into four equal squares so that the lighting measurement can be taken at the center of these divided areas. Lighting measurements were taken at $0.85 \mathrm{~m}$ above the floor level. Then readings were recorded accordingly. These measurement methods are referred to from Guidelines on Occupational Safety and Health for Lighting at Workplace [19].

Three hundred seventy-eight (378) questionnaires were administered, but only three hundred twelve (312) questionnaires were received back, therefore the rate of response is $82.54 \%$. Among the three hundred twelve (312) respondents, two hundred sixty (260) are the students and fifty-two (52) are lecturers who are using the chosen location frequently. 176 or $56 \%$ are male respondents and 136 or $44 \%$ are female respondents. All the respondents are selected randomly, therefore there is no gender discrimination in the respondent selection process. The majority of respondents are from the Faculty of Engineering and Green Technology which is $34 \%, 26 \%$ of respondents are from the Faculty of Business and Finance, $21 \%$ of the respondents from the Foundation, 9\% of respondents from the Faculty of Information and Communication Technology, $6 \%$ of respondents from the Faculty of Science and $4 \%$ of respondents from the Faculty of Arts and Social Science. The lux meter measurement and questionnaire were conducted in the same period, which is in the middle of the long semester of 2019. This questionnaire contains six (6) questions in Part A which is the demography section, eleven (11) questions in Part B which is true or false questions, eight (8) questions in Part $\mathrm{C}$ which is true or false the questions and fifteen (15) questions in Part D which is Likert scale. Scale number 1 specifies strongly disagree and scale number 5 specifies strongly agree. Only Part D will be discussed in this paper. Descriptive analysis and T-Test were used to analyze fifteen (15) questions in the questionnaires.

\subsection{The Characteristics of the Lecture Theatres and Tutorial Rooms}

The lecture theatres (auditorium seating) have no windows which allow natural lighting to come in. All the lecture theatres in all the blocks used in this research are sharing the same design. The white color of paint is used in this lecture theatre. Where else, the tutorial rooms have slightly different designs. Tutorial rooms in Block $\mathrm{R}$ and Block $S$ are sharing the same design. Tutorial rooms in Block $\mathrm{T}$ and Block $\mathrm{U}$ are sharing the same design. Tables and chairs of the students are placed close by to the whiteboard to provide a good view to the students. Detailed specifications of the lecture theatre are shown in Table 3.

\subsection{The Obstructions in the Research Venues}

There are blocks adjacent to all the researched blocks that obstruct the natural lighting received from the right side of the tutorial rooms. Tall trees were planted are about 17 feet from each block. Those trees have grown up to 10 feet high and the shade from these trees is obstructing the natural lighting from the left side of the room. Due to these reasons, poor daylight illuminance was recorded in all the tutorial rooms which require artificial to be used even in the daytime. Kampar area is full of many mountains and due to this reason, heavy rain is frequent. If the sky becomes gloomy and fully overcast without any sunlight, then these rooms used in this research need to rely on artificial lightings to bright up the rooms.

\subsection{The Limitations in this Research}

There are several limitations while conducting this research, such as due to some of the bulbs in both lecture theatre and tutorial rooms are not functioning, therefore there will be a huge difference in the lumen (1x) collected in the rooms which have fully functional bulbs. This may raise a question of accuracy. Respondents with good vision (without wearing glasses) or short sight (be wearing glasses) were not taken into consideration for this research. The buildings used in this research were constructed in 2002 and following the wear and tear concept.

\section{Results and Discussion}

The result section is divided into two (2) sections which are the comparison of the illuminance level in lecture theaters and tutorial rooms and to identify the users' perceptions of the illuminance level in both lecture theaters and tutorial rooms in UTAR. 
Table 3. Detail specifications of the research locations.

\begin{tabular}{|c|c|c|c|c|c|c|}
\hline Location & $\begin{array}{l}\text { Size of the } \\
\text { room }\end{array}$ & $\begin{array}{l}\text { Number } \\
\text { of doors }\end{array}$ & $\begin{array}{l}\text { Number of } \\
\text { windows }\end{array}$ & Ventilation & Bulb's specification & $\begin{array}{l}\text { Capacity } \\
(\operatorname{pax})\end{array}$ \\
\hline $\begin{array}{l}\text { Lecture } \\
\text { theatre }\end{array}$ & $\begin{array}{l}12225 \mathrm{~mm} \\
\text { (length) } \mathrm{x} \\
21225 \mathrm{~mm} \\
\text { (width). }\end{array}$ & 3 & 0 & $\begin{array}{l}\text { No fans, } \\
\text { operating } \\
\text { under } \\
\text { centralized air- } \\
\text { conditioning } \\
\text { units }\end{array}$ & $\begin{array}{l}\text { - } 40 \text { units of } 14 \text { watts } \\
\text { of white downlights } \\
\text { (One } 1 \text {-way switch } \\
\text { is controlling (6) } \\
\text { fluorescent bulbs in } \\
\text { the downlights at } \\
\text { once) } \\
\text { - } 4 \text { units of } 12 \text { watt of } \\
\text { yellow highlights } \\
\text { (One 1-way switch } \\
\text { is controlling (4) } \\
\text { yellow highlight } \\
\text { bulbs at once) }\end{array}$ & 150 \\
\hline $\begin{array}{l}\text { Tutorial } \\
\text { room } \\
\text { (Block R } \\
\text { and Block } \\
\text { S) }\end{array}$ & $\begin{array}{l}8474 \mathrm{~mm} \\
\text { (length) } \mathrm{x} \\
12225 \mathrm{~mm} \\
\text { (width) }\end{array}$ & 1 & $\begin{array}{l}3 \text { large panels } \\
\text { at the back of } \\
\text { the } \\
\text { classroom }\end{array}$ & $\begin{array}{l}\text { No fans, } \\
\text { operating } \\
\text { under } \\
\text { centralized air- } \\
\text { conditioning } \\
\text { units }\end{array}$ & $\begin{array}{l}\text { - } 36 \text { units of } 14 \text { watts } \\
\text { of downlights } \\
\text { - } 5 \text { rows of } 6 \text { units of } \\
8 \text { watts of short } \\
\text { fluorescent LED } \\
\text { bulbs }\end{array}$ & 80 \\
\hline $\begin{array}{l}\text { Tutorial } \\
\text { room } \\
\text { (Block T } \\
\text { and Block } \\
\text { U) }\end{array}$ & $\begin{array}{l}8474 \mathrm{~mm} \\
\text { (length) x } \\
12225 \mathrm{~mm} \\
\text { (width) }\end{array}$ & 2 & $\begin{array}{l}\text { - } 3 \text { large } \\
\text { windows } \\
\text { with } 2 \\
\text { panels and } \\
1 \text { large } \\
\text { window } \\
\text { with } 1 \\
\text { panel at } \\
\text { the left } \\
\text { side of the } \\
\text { classroom } \\
\text { - } 3 \text { large } \\
\text { windows } \\
\text { with } 2 \\
\text { panels and } \\
3 \text { large } \\
\text { windows } \\
\text { with } 3 \\
\text { panels at } \\
\text { the right } \\
\text { side of the } \\
\text { classroom }\end{array}$ & $\begin{array}{l}\text { No fans, } \\
\text { operating } \\
\text { under } \\
\text { centralized air- } \\
\text { conditioning } \\
\text { units }\end{array}$ & $\begin{array}{l}\text { - } 36 \text { units of } 14 \text { watts } \\
\text { of downlights } \\
\text { - } 5 \text { rows of } 6 \text { units of } \\
8 \text { watts of short } \\
\text { fluorescent LED } \\
\text { bulbs }\end{array}$ & 80 \\
\hline
\end{tabular}

\subsection{Comparison of the Illuminance Level in Lecture} Theaters and Tutorial Rooms in UTAR

Based on Table 4, the average readings from the lux meter in the selected lecture theatres are within the range of 300-500lux which is in the recommended category for the classroom and library in MS1525 2014 [9]. Four (4) points were selected to measure the accurate readings due to the various seating types in the lecture theatre. Four (4) different blocks were selected as samples for this research. 
Table 4. Lux meter result for lecture theatres in Block R, Block S, Block T and Block U.

\begin{tabular}{|c|c|c|c|c|c|}
\hline \multicolumn{6}{|c|}{ Block R } \\
\hline Block R & Point I & Point II & Point III & Point IV & Average(lx) \\
\hline RSA & 365 & 276 & 223 & 225 & 272 \\
\hline RSB & 381 & 371 & 429 & 421 & 401 \\
\hline RSC & 433 & 560 & 364 & 412 & 442 \\
\hline RSD & 391 & 281 & 349 & 319 & 335 \\
\hline RSE & 381 & 358 & 225 & 355 & 330 \\
\hline \multicolumn{6}{|c|}{ Block S } \\
\hline Block S & Point I & Point II & Point III & Point IV & Average(lx) \\
\hline SSA & 368 & 423 & 435 & 350 & 372 \\
\hline SSB & 350 & 478 & 450 & 338 & 388 \\
\hline SSC & 534 & 323 & 432 & 352 & 400 \\
\hline SSD & 433 & 452 & 305 & 385 & 378 \\
\hline SSE & 439 & 358 & 329 & 468 & 416 \\
\hline \multicolumn{6}{|c|}{ Block T } \\
\hline Block T & Point I & Point II & Point III & Point IV & Average(lx) \\
\hline TSA & 448 & 451 & 382 & 443 & 431 \\
\hline TSB & 385 & 435 & 444 & 373 & 409 \\
\hline TSC & 366 & 328 & 405 & 477 & 394 \\
\hline TSD & 302 & 400 & 376 & 394 & 368 \\
\hline TSE & 379 & 360 & 484 & 295 & 380 \\
\hline TSF & 446 & 424 & 450 & 338 & 415 \\
\hline TSG & 303 & 335 & 432 & 352 & 356 \\
\hline \multicolumn{6}{|c|}{ Block U } \\
\hline Block U & Point I & Point II & Point III & Point IV4 & Average(lx) \\
\hline USA & 411 & 414 & 404 & 443 & 418 \\
\hline USB & 321 & 463 & 393 & 373 & 388 \\
\hline USC & 326 & 425 & 346 & 477 & 394 \\
\hline USD & 324 & 428 & 326 & 394 & 368 \\
\hline USE & 357 & 475 & 331 & 295 & 365 \\
\hline
\end{tabular}

Table 5, shows that the illuminance level in some of the venues in Block $\mathrm{R}$, Block $\mathrm{T}$, and Block $\mathrm{U}$ is slightly higher than the range recommended illuminance levels for classroom and library in MS1525 2014 [9]. One (1) tutorial room in Block R, four (4) in Block S, and the tutorial rooms in Block $\mathrm{U}$ recorded above 500lux. This reading indicates that these tutorial rooms are over illuminance and too bright. This over illuminance is caused by the usage of artificial lights compared to the natural lighting, lights which are provided are in too much of intensity and only few control switches are available in each room which makes many lights are turned on at once when the control switches are on. Some of the tutorial rooms are equipped with three (3) large window panels which can be used as a natural lighting source to substitute the artificial lighting. Switches for the electric lights can be turned off when the sun is out there to reduce the illuminance level and to reduce the utility bills. Because on one switch control six (6) bulbs at once it is quite difficult to control the illuminance level in the tutorial rooms. White bulbs used in all the lectures and tutorial rooms, light bulbs are good in terms of illuminance because it does not create any shadows but then it creates fatigue in prolonged usage. Over illuminance can be one of the causes of physical damage to the eyes, stress, anxiety, medical stress, and even psychological disorders [2]. 
Table 5. Lux meter result for tutorial rooms in Block R, Block S, Block T, and Block U.

\begin{tabular}{|c|c|c|c|c|c|}
\hline \multicolumn{6}{|c|}{ Block R } \\
\hline Lower Level & Point I & Point II & Point III & Point IV & Average(lx) \\
\hline R001 & 458 & 428 & 424 & 421 & 433 \\
\hline R002 & 393 & 326 & 495 & 375 & 397 \\
\hline R003 & 323 & 302 & 360 & 426 & 353 \\
\hline R004 & 442 & 399 & 402 & 430 & 418 \\
\hline R005 & 335 & 388 & 499 & 419 & 410 \\
\hline R006 & 421 & 324 & 386 & 446 & 394 \\
\hline R007 & 318 & 360 & 473 & 357 & 377 \\
\hline R008 & 326 & 412 & 442 & 334 & 379 \\
\hline R009 & 379 & 337 & 405 & 348 & 367 \\
\hline Upper Level & Point I & Point II & Point III & Point IV & Average(lx) \\
\hline R101 & 375 & 329 & 390 & 314 & 352 \\
\hline R102 & 300 & 330 & 430 & 385 & 361 \\
\hline R103 & 430 & 428 & 389 & 401 & 412 \\
\hline R104 & 325 & 365 & 330 & 385 & 351 \\
\hline R105 & 570 & 532 & 453 & 473 & 507 \\
\hline R106 & 439 & 423 & 389 & 410 & 415 \\
\hline R107 & 338 & 398 & 430 & 436 & 401 \\
\hline R108 & 562 & 355 & 385 & 483 & 446 \\
\hline R109 & 385 & 460 & 456 & 463 & 441 \\
\hline R110 & 324 & 396 & 382 & 402 & 376 \\
\hline R111 & 330 & 310 & 420 & 450 & 378 \\
\hline R112 & 333 & 345 & 328 & 355 & 340 \\
\hline R113 & 320 & 356 & 330 & 332 & 335 \\
\hline R114 & 230 & 270 & 330 & 285 & 279 \\
\hline R115 & 313 & 260 & 335 & 325 & 308 \\
\hline \multicolumn{6}{|c|}{ Block S } \\
\hline Lower Level & Point I & Point II & Point III & Point IV & Average(lx) \\
\hline S001 & 321 & 430 & 386 & 370 & 377 \\
\hline S002 & 331 & 384 & 412 & 432 & 390 \\
\hline S003 & 520 & 541 & 491 & 511 & 516 \\
\hline S004 & 580 & 521 & 616 & 533 & 563 \\
\hline Upper Level & Point I & Point II & Point III & Point IV & Average(1x) \\
\hline S101 & 476 & 483 & 445 & 478 & 471 \\
\hline S102 & 690 & 576 & 658 & 571 & 624 \\
\hline S103 & 393 & 380 & 396 & 385 & 389 \\
\hline S104 & 515 & 550 & 518 & 508 & 523 \\
\hline S105 & 575 & 561 & 540 & 538 & 554 \\
\hline S106 & 393 & 533 & 545 & 467 & 485 \\
\hline S107 & 500 & 484 & 533 & 481 & 500 \\
\hline S108 & 270 & 428 & 379 & 328 & 351 \\
\hline S109 & 303 & 357 & 308 & 328 & 324 \\
\hline \multicolumn{6}{|c|}{ Block T } \\
\hline Lower Level & Point I & Point II & Point III & Point IV & Average(lx) \\
\hline T001 & 445 & 487 & 376 & 388 & 424 \\
\hline T0002 & 521 & 512 & 469 & 491 & 498 \\
\hline
\end{tabular}




\begin{tabular}{|c|c|c|c|c|c|}
\hline Upper Level & Point I & Point II & Point III & Point IV & Average(lx) \\
\hline T101 & 382 & 422 & 328 & 352 & 371 \\
\hline T102 & 332 & 377 & 354 & 348 & 353 \\
\hline T103 & 483 & 398 & 421 & 409 & 428 \\
\hline T104 & 331 & 395 & 421 & 418 & 391 \\
\hline T105 & 306 & 323 & 318 & 378 & 331 \\
\hline T106 & 341 & 319 & 333 & 368 & 340 \\
\hline \multicolumn{6}{|c|}{ Block U } \\
\hline Lower Level & Point I & Point II & Point III & Point IV & Average(lx) \\
\hline U001 & 649 & 631 & 721 & 689 & 673 \\
\hline U002 & 632 & 743 & 628 & 656 & 665 \\
\hline U003 & 668 & 659 & 619 & 651 & 649 \\
\hline U004 & 745 & 608 & 605 & 699 & 664 \\
\hline U005 & 526 & 560 & 663 & 651 & 600 \\
\hline U006 & 531 & 498 & 605 & 458 & 523 \\
\hline U007 & 607 & 574 & 731 & 630 & 636 \\
\hline U008 & 647 & 650 & 733 & 626 & 664 \\
\hline U009 & 606 & 637 & 656 & 536 & 609 \\
\hline U010 & 622 & 639 & 692 & 733 & 672 \\
\hline U011 & 658 & 604 & 580 & 781 & 656 \\
\hline U012 & 514 & 603 & 574 & 489 & 545 \\
\hline U013 & 626 & 664 & 588 & 559 & 609 \\
\hline U014 & 689 & 569 & 528 & 711 & 624 \\
\hline U015 & 517 & 672 & 631 & 577 & 599 \\
\hline U016 & 538 & 641 & 470 & 665 & 579 \\
\hline U017 & 633 & 574 & 709 & 678 & 649 \\
\hline U018 & 604 & 584 & 532 & 555 & 569 \\
\hline Upper Level & Point I & Point II & Point III & Point IV & Average(lx) \\
\hline U101 & 685 & 669 & 589 & 613 & 639 \\
\hline U102 & 723 & 610 & 620 & 567 & 630 \\
\hline U103 & 668 & 651 & 601 & 621 & 635 \\
\hline U104 & 583 & 595 & 672 & 638 & 622 \\
\hline U105 & 603 & 731 & 625 & 572 & 633 \\
\hline U106 & 681 & 677 & 579 & 541 & 620 \\
\hline U107 & 677 & 603 & 623 & 633 & 634 \\
\hline U108 & 640 & 568 & 656 & 612 & 619 \\
\hline U109 & 634 & 655 & 613 & 723 & 656 \\
\hline U110 & 580 & 567 & 603 & 741 & 623 \\
\hline U111 & 581 & 622 & 616 & 562 & 595 \\
\hline U112 & 606 & 574 & 621 & 596 & 599 \\
\hline U113 & 567 & 597 & 613 & 647 & 606 \\
\hline U114 & 642 & 633 & 664 & 645 & 646 \\
\hline U115 & 603 & 640 & 504 & 638 & 596 \\
\hline U116 & 630 & 677 & 597 & 515 & 605 \\
\hline U117 & 677 & 641 & 586 & 653 & 639 \\
\hline
\end{tabular}


3.2. Descriptive Analysis for Lecturer and Student's Perception on the Illuminance Level in the Lecture Theatre and Tutorial Rooms

The reliability test Section D is shown in Table 6 and the validity test for Section D is shown in Table 7. Table 6 shows that the Cronbach's Alpha of reliability test for Section D is very high. Furthermore, Cronbach's Alpha is within 0.7 to 0.9 , which means a good internal consistency.

Table 7 shows the KMO test value for Section B which is 0.819 . The degree of common variance is praiseworthy as the KMO's test value is between 0.80 and 0.89 . Adding to this, there is a strong relationship between the variables in Section D as Bartlett's Test of Sphericity value is lesser than 0.001 .

Table 6. Cronbach's Alpha for internal validity.

\begin{tabular}{llll}
\hline $\begin{array}{l}\text { Cronbach's } \\
\text { Alpha }\end{array}$ & $\begin{array}{l}\text { Cronbach's } \\
\text { Based } \\
\text { Standardized Items }\end{array}$ & $\begin{array}{r}\text { Alpha } \\
\text { on }\end{array}$ & $\begin{array}{l}\text { N of Items } \\
\end{array}$ \\
\hline 0.859 & 0.841 & 15 \\
\hline
\end{tabular}

Table 7. KMO and Bartlett's Test.

\begin{tabular}{llc}
\hline KMO And Bartlett's Test & & \\
\hline Kaiser-Meyer-Olkin Measure of Sampling Adequacy & & 0.819 \\
Bartlett's Test of Sphericity & Approx. Chi-Square & 3927.365 \\
& df & 105 \\
& Sig. & 0.000 \\
\hline
\end{tabular}

Based on Table 8 , the lowest mean recorded is 2.10 and the highest mean is 3.77. Hence, almost all the respondents feel that the illuminance level is vital in a learning environment. The illuminance level will affect the user's presentation, attitude and health are at the highest rank and light cause headache and eye fatigue are at the lowest in the rank which is 2.10 . The result also shows that almost all the respondents are satisfied with the illuminance level in both research venues. The result shows that the illuminance level in selected blocks does not create distress among the respondents. However, UTAR can still take some effort to reduce the usage of artificial lighting by restricting the use of the artificial lights during the sunny day or installing the artificial lighting with a sensor which switches off the lights when no one is in the designated room for a certain period.

Table 8. Lux meter result for tutorial rooms in Block B, Block E, Block H, and Block N.

\section{Descriptive Statistics}

\begin{tabular}{|c|c|c|c|c|c|c|}
\hline & $\mathbf{N}$ & Min & Max & Mean & $\begin{array}{l}\text { Std. } \\
\text { Deviation }\end{array}$ & Ranking \\
\hline $\begin{array}{l}\text { Illuminance is important in learning } \\
\text { environment. }\end{array}$ & 312 & 3 & 5 & 3.77 & 0.465 & 1 \\
\hline $\begin{array}{l}\text { Illuminance will affect the user's } \\
\text { performance. }\end{array}$ & 312 & 3 & 5 & 3.68 & 0.499 & 2 \\
\hline Illuminance will affect the user's health. & 312 & 1 & 5 & 3.63 & 0.535 & 5 \\
\hline Illuminance will affect the user's mood. & 312 & 3 & 5 & 3.66 & 0.500 & 4 \\
\hline Illuminance will affect visual performance. & 312 & 3 & 5 & 3.67 & 0.522 & 3 \\
\hline $\begin{array}{l}\text { Satisfied the illuminance level in UTAR } \\
\text { learning environment. }\end{array}$ & 312 & 3 & 5 & 3.46 & 0.506 & 6 \\
\hline $\begin{array}{l}\text { Satisfied the light colour in lecture theatre } \\
\text { and tutorial class. }\end{array}$ & 312 & 3 & 5 & 3.40 & 0.516 & 7 \\
\hline $\begin{array}{l}\text { Satisfied the lighting condition in lecture } \\
\text { theatre and tutorial class. }\end{array}$ & 312 & 3 & 5 & 3.36 & 0.507 & 8 \\
\hline The light makes you feel headache. & 312 & 1 & 5 & 2.10 & 0.613 & 13 \\
\hline You felt warm under the light. & 312 & 1 & 5 & 2.14 & 0.628 & 11 \\
\hline $\begin{array}{l}\text { You felt visual distraction during lecture } \\
\text { theatre and tutorial class. }\end{array}$ & 312 & 1 & 5 & 2.11 & 0.692 & 12 \\
\hline $\begin{array}{l}\text { You felt visual discomfort during lecture } \\
\text { theatre and tutorial class. }\end{array}$ & 312 & 1 & 5 & 2.15 & 0.651 & 10 \\
\hline $\begin{array}{l}\text { You felt eye fatigue during lecture theatre } \\
\text { and tutorial class. }\end{array}$ & 312 & 1 & 5 & 2.10 & 0.685 & 13 \\
\hline $\begin{array}{l}\text { Your eye felt dry during lecture theatre and } \\
\text { tutorial class. }\end{array}$ & 312 & 1 & 4 & 2.11 & 0.654 & 12 \\
\hline $\begin{array}{l}\text { You have difficulties in seeing an object on } \\
\text { the screen. }\end{array}$ & 312 & 1 & 5 & 2.17 & 0.710 & 9 \\
\hline Valid N & 312 & & & & & \\
\hline
\end{tabular}


Table 9 is used to determine whether is there any differences between the perception of the lectures and the students regarding the illuminance level in the lecture theatre and tutorials in the selected block. From Table 7, it is found that a paired sample test was conducted on a sample of 312 respondents to identify whether there was a statically significant similarity between tutorial class and lecture theatre. Pair 1 is about the lighting condition in the learning environment which is preferred by the respondent while pair 2 is about the condition in both of the research venues which includes the existence of glaring vision, the existence of headache, and eye tiredness, and conditions which affect student performance. According to the result, the Sig (2-tailed) for pair 1 and pair 2 is greater than 0.05 . Hence, it is determined that there is no notable difference in both research venues. But, the mean difference occurs due to the users' personal preferences which difficult to determine.

Table 9. Lux meter result for tutorial rooms in Block R, Block S, Block T, and Block U.

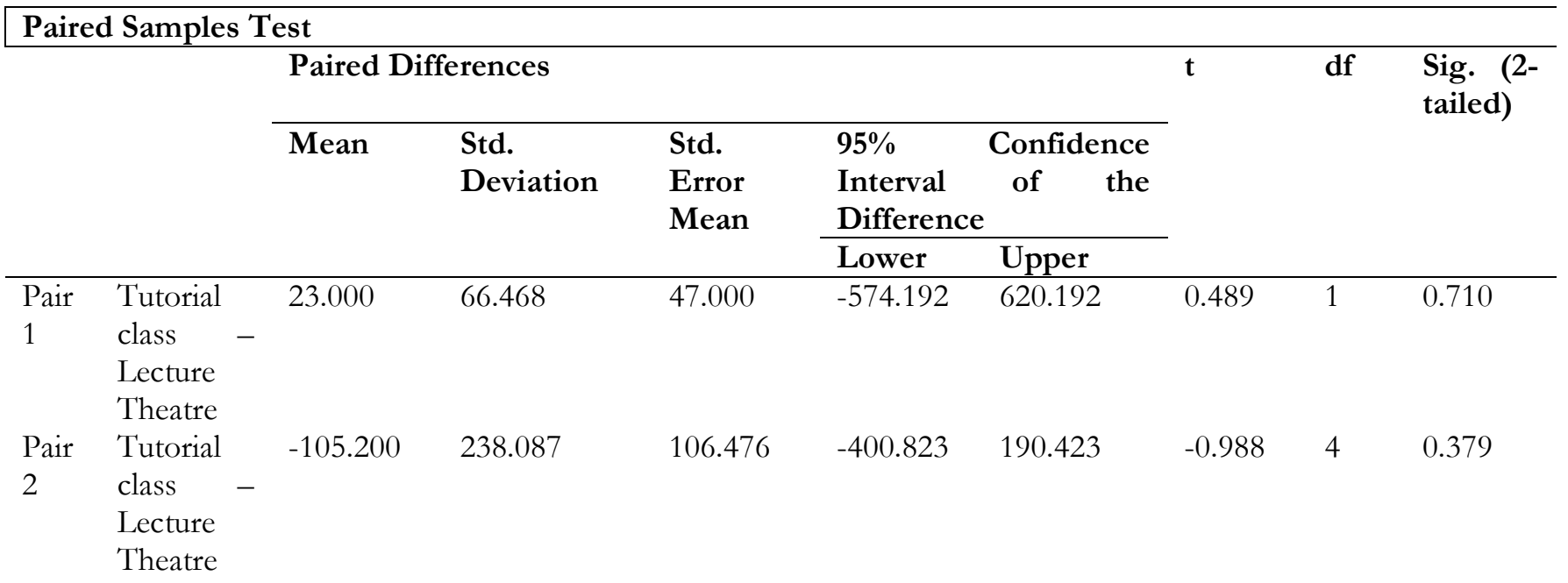

\section{Recommendation and Conclusion}

From the results, it is found that the average readings of illuminance level are quite high in several blocks compared to the average readings recommended for the classroom and library. Even though the result shows that the illuminance level in the sample blocks in this research did not make the respondents feel discomfort, but some effort can be taken to switch off to the lights when it is not in use. For the rooms which have high lux reading, individual switches can be provided for each of the bulbs to control the illumination level manually by the students and lecturers because currently, one (1) switch is controlling four (4) or six (6) at once. Students and lecturers can also adjust the illuminance in the specific rooms by just switching on the required bulbs only instead of switching all of them. Since all the tutorial rooms have large window panels, students and lecturers should be considering natural daylighting whenever it is possible instead of always relying totally on artificial lighting. For the lecture theatre, students and lecturers cannot adjust their level of illuminance as per their preferences since there no window panels therefore dependency on artificial lighting cannot be avoided. If the university is considering building new buildings soon, then they can consider adding more windows to allow more natural lighting into the buildings. Illuminance level not only affects the learning environment, but it also affects the mood of the students when they are trying to grasp the knowledge given by their lecturers. Generally, artificial lighting is essential on the days where the sun is not available or gloomy day, but on the other hand, over illuminance can be led several negative issues which can be harmful to the users. If the illuminance level is low, it will lead to seasonal affective disorder.

This study shows how illuminance level affects the student's concentration in the class. A learning environment with a decent quality of light is essential to the users because this will influence the knowledge receiving process and concentration span. Students are required to read on different surfaces, namely the writing on their notes or the screen projector in front of the class and they must always adjust their gaze [19]. This research is also important to make some improvements to the lighting system in the learning environment, natural lighting is always considered the best source of lights due to its positive effects on the users. This paper concludes by suggesting the university consider natural lighting whenever it is possible to mitigate the health issues caused by over illuminance.

\section{Acknowledgment}

My sincere appreciation and thanks to the Centre for Environment and Green Technology of the Faculty of Engineering and Green Technology (FEGT), Universiti Tunku Abdul Rahman (UTAR) for their support. Thank you. 


\section{References}

[1] N. T. Al-Ashwal and A. S. Hassan, "The impact of daylighting-artificial lighting integration on building users' health and performance," International Transaction Journal of Engineering, Management \& Applied Sciences \& Technologies, vol. 9, no. 2, pp. 97-105, 2018.

[2] Z. M. Seman, L. Sheau-Ting, R. Mansor, W. SiawChui, and S. Zulfarina, "Classroom illuminance: A case in Malaysian university," IOP Conf. Series: Materials Science and Engineering, vol. 849, pp. 1-7, 2020.

[3] Department of Occupational Safety and Health, Guidelines on Occupational Safety and Health for Lighting at Workplace. 2018.

[4] P. Singh and R. Arora, "Classroom illuminance: Its impact on students' health exposure and concentration performance," in Proc. International Ergonomics Conference HWWE 2014, December 3-5, 2014, Assam, India, 2014, pp. 1-6.

[5] F. Arabi, E. M. Husini, R. N. Syaheeza, Y. A. Dodo, and M. Z. Kandar, "Acceptable illuminance level attributes to learning satisfaction in classroom," in Proc. of the IRES International Conference, December 1112, 2017, Lisbon, Portugal, 2017, pp. 9-14.

[6] A. D. Mathalamuthu, N. L. N. Ibrahim, V. Ponniah, M. W. M. Shafiei, and R. Ismail, "Illuminance uniformity using Public Works Department (PWD) standard design for public schools classroom design in Malaysia," Journal of Advanced Research in Fluid Mechanics and Thermal Sciences, vol. 52, no. 2, pp. 205214, 2018.

[7] E. M. Husini, "User Density and Daylight Illuminance Level Fluctuation for Office Building in Malaysia," Ph.D. thesis, Universiti Teknologi Malaysia, 2016.

[8] R. N. Syaheeza, E. M. Husini, M. K. Khamis, M. F. Zolkelfli, and Y. A. Dodo, "Illuminance level measurement at lower working plane height in Islamic religious school," Asian Journal of University Education (AJUE), vol. 16, no. 3, pp. 125-137, 2020.

[9] Energy Efficiency and Use of Renewable Energy for NonResidential Buildings, MS 1525, Malaysian Standards, Malaysia, 2014.

[10] E. M. Husini, R. N. Syaheeza, M. Arabi, W. Norisma, and N. H. Jaafar, "Light, daylighting and fluctuation of illuminance level in office buildings," in Proc. 2nd International Conference on Architecture and Civil Engineering (ICACE 2018), Penang, Malaysia, 2018, pp. 1-7.
[11] M. Kim, D. H. Jeon, J. S. Kim, B. C. Yu, Y. Park, and S. W. Lee, "Optimum display luminance depends on white luminance under various ambient illuminance conditions," Optical Engineering, vol. 57, no. 2, pp. 0241061-0241069, 2019.

[12] J. Duff, K. Kelly, and C. Cuttle, "Perceived adequacy of illumination, spatial brightness, horizontal illuminance and mean room surface existence in a small office," Lighting Research and Technology, vol. 49, no. 2, pp. 1-23, 2015.

[13] M. Hsieh, "Effects of illuminance distribution, colour temperature and illuminance level on positive and negative moods," Journal of Asian Architecture and Building Engineering, vol. 14, no. 3, pp. 709-716, 2015.

[14] P. R. Hebert, G. G. Peek, M. Kang, and X. Zhang, "Illuminance levels in social spaces of an older adult facility," Industrial and Systems Engineering, vol. 2, no. 2, pp. 21-27, 2017.

[15] M. Wintertbottom and A. Wilkins, "Lighting and discomfort in the classroom," Journal of Environmental Psychology, vol. 29, pp. 63-75, 2009.

[16] N. Shishegar and M. Boubekri, "Natural light and productivity: Analysing the impacts of daylighting on students' and workers' health and alertness," International Journal of Advances in Chemical Engineering \& Biological Sciences (IJACEBS), vol. 3, no. 1, pp. 7277, 2016.

[17] I. Turekova, D. Lukacova, and G. Banesz, "Quality assessment of the university classroom lighting: A case study," Technology, Education, Management, Informatics Journal, vol. 7, no. 4, pp. 829-836, 2018.

[18] S. A. Samani and S. A. Samani, "The impact of indoor lighting on students' learning performance in learning environments: A knowledge internalization perspective," International Journal of Business and Social Science, vol. 3, no. 24, pp. 127- 136, 2012.

[19] A. S. Pulay, "Awareness of daylighting on student learning in an educational facility," Master's Thesis, University of Nebraska, 2010.

[20] Department of Occupational Safety and Health, Guidelines on Occupational Safety and Health for Lighting at Workplace. 2018.

[21] J. M. Katabaro and Y. Yan, "Effects of lighting on working efficiency of workers in office building in Tanzania," Journal of Environmental and Public Health, 2019.

[22] M. D. Anselm, N. Ibrahim, and N. Lukman, "Evaluation of daylighting at public school classrooms in Ipoh, Perak," Alam Cipta., vol. 7, no. 1, pp. 27-34, 2014. 


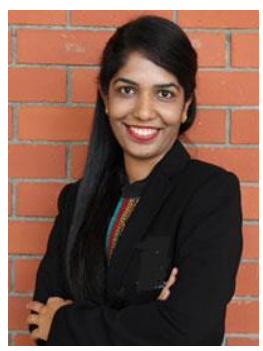

Shalini Sanmargaraja was born in Taiping, Perak, Malaysia in 1986. She received early education at the Raja Perempuan Secondary School in Ipoh, Perak, Malaysia. She continued her studies at the undergraduate level in Universiti Tun Hussein Onn Malaysia (UTHM) and managed to pursue her Bachelor's degree with Honours in Technology Management (Construction) in 2010. She then enrolled at Universiti Tun Hussein Onn Malaysia in 2010, where she was awarded MSc. in Real Estate and Facilities Management in 2012. During her studies, she was a research assistant in Universiti Tun Hussein Onn Malaysia under the sponsorship of the Graduate School. In the year 2013, she pursued her third degree in the Ph.D. program in the Faculty of Technology Management and Business under the MyBrain Scholarship Scheme from the Ministry of Higher Education of Malaysia (MOHE). In 2017, she was awarded Doctor of Philosophy in Real Estate and Facilities Management. Her research interests are indigenous studies, human population studies, facilities for the disabled society, construction management, green technology, sustainable construction, sustainable and affordable housing, and sustainable development.

During her master studies, she wrote three (3) proceedings papers in the field of facility management in the old folks' home in three (3) international conferences. During her doctoral studies, she managed to produce seventeen (17) proceedings and eleven (11) International journals. She was awarded the best paper award in the International Conference on Business Management and Information Technology (ICBMIT) in the year 2014. During this time, she managed to be the co-author in producing a book entitled Isu Penuaan dan Fasiliti di Rumab Orang Tua. Adding to this, she managed to publish (3) more chapters of books, one (1) international journal, and three (3) proceedings.

Dr. Shalini is now attached to Universiti Tunku Abdul Rahman (UTAR) as an Assistant Professor. Dr. Shalini later joined the Technological Association of Malaysia (TAM) and the Malaysian Board of Technologists (MBOT). In 2021, Dr. Shalini was awarded Profesional Technologist (Ts) title by the Malaysian Board of Technologists (MBOT).

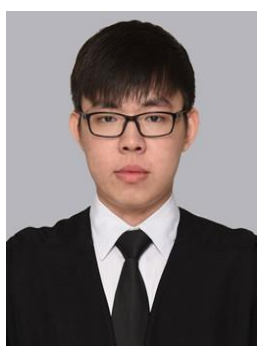

Tew Li Wei was born in Kelantan, Malaysia in 1996. He received a bachelor's degree in Construction Management, Faculty Engineering, and Green Technology from University Tunku Abdul Rahman in 2020. Currently, he is attached to Kerjaya Prospek as a junior site supervisor.

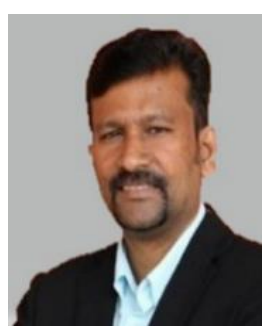

Vignes Ponniah was born in Penang, Malaysia in 1979. He received the Bachelor of Science (Hons) in Building Technology from Universiti Sains Malaysia, Penang, Malaysia in 2003 and Master of Project Management from Open University Malaysia, Kuala Lumpur, Malaysia in 2011. Besides that, as the highest academic qualification, he received the Ph.D. degree in Green Construction Management from Universiti Sains Malaysia, Penang, Malaysia in 2016. From 2016 to 2018, he was working as a Senior Lecturer with the Tunku Abdul Rahman University College, Kuala Lumpur, Malaysia. Since 2018, he was attached to Universiti Tunku Abdul Rahman under the Faculty of Engineering and Green Technology in the Department of Construction Management as an Assistant Professor. He is the author of one chapter by book and 18 international journal articles and conference proceedings. His research interests are related to sustainable development, energy modeling, and the energy performance of buildings. Furthermore, Dr. Vignes has several years of experience working in companies that involve in construction and property management before joining the academic institution. Dr. Vignes is also a certified GreenRE Manager from GreenRE Malaysia after completing the certification course and having fulfilled the specific requirements since the year 2017.

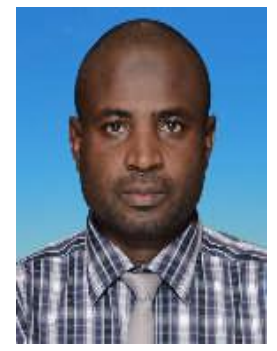

Abdul Lateef A. Olanrewaju is an assistant professor at Universiti Tunku Abdul Rahman. He gained his Master of Science in the built environment from the International Islamic University Malaysia in 2007 and his doctorate from Universiti Teknologi PETRONAS Malaysia in 2012. He received his quantity surveying education at Kaduna Polytechnic, Nigeria. His academic activities center on lecturing and research associated with value management, research methodology, and construction project management. He has authored and co-authored several scientific papers. Olanrewaju is a referee for leading journals. His current research and proficiency concentrate on building maintenance, affordable housing delivery, ethical issues in the construction industry, procurement, quantity surveying, and value management. 


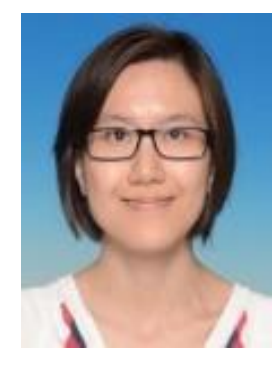

Khor Soo Cheen was born in Khor's family in the year of 1982. Her hometown is located in the northernmost states on the west coast of Peninsular Malaysia. She received her primary and secondary education at the school of Perlis, Malaysia. She enrolled in the School of Housing, Building, and Planning (HBP) to continue her undergraduate degree at Universiti Sains Malaysia (USM) after STPM and received her bachelor's degree in 2003. She continued to pursue her graduate level at the same school in USM. She has been awarded her MSc and Ph.D. in 2007 and 2014 in respectively. She has been involved in teaching and working for a few firms in the construction sector and other related works since her undergraduate study. As an academician, she has also been involved in numerous researches and worked as a researcher in the School of HBP. Her areas of interest are construction industry development, housing development, green building, and sustainable construction management. During her studies, she managed to publish her research in an international journal, conference proceedings, and book chapters. Last but not least, she received a scholarship from USM while pursuing her Ph.D. program. Dr. Khor currently working at Universiti Tunku Abdul Rahman (UTAR) with holding the position of assistant professor for her affiliated department (Construction Management, CM). She is teaching project and construction management courses at both undergraduate and graduate-level at the Faculty of Engineering and Green Technology (FEGT). She joined Technological Association Malaysia (TAM) for which her career is related to technological. 